\title{
Changes in serum enzyme levels accompanying cardiac surgery with extracorporeal circulation
}

\author{
NORA WELBOURN¹, D. G. MELROSE, AND D. W. MOSS ${ }^{2}$ \\ From the Nuffield Unit of Clinical Physiology, Departments of Surgery and \\ Chemical Pathology, Postgraduate Medical School, London
}

SYNOPSIS Serum lactic dehydrogenase, alpha-hydroxy-butyrate dehydrogenase, iso-citric dehydrọgenase, and glutamic oxaloacetic transaminase activities were measured daily for two weeks postoperatively in the serum of 22 patients undergoing cardiac surgery with extracorporeal circulatioin.

The length of perfusion was found to be a major factor affecting the extent of increased post? operative enzyme activities. Significantly higher levels were demonstrated in patients perfused for over one hour compared with those perfused for under one hour. Hepatocellular damage, age, and type $\mathrm{a} f$ operation were not considered to be major factors in determining the extent of this increased activit

A considerable increase in enzyme activity was found to occur during perfusion when the dilution introduced by mixing the patient's circulation with the priming fluid of the heart-lung machine w $\overrightarrow{\mathrm{as}}$ taken into account. This dilution, when accounted for, increased the observed enzyme activity by 30 to $50 \%$.

The association of raised serum enzyme levels with damage to heart muscle, e.g., myocardial infarction, is well documented. However, in patients undergoing cardiac surgery with extracorporeal circulation further study appeared to be necessary to elucidate the role extracorporeal circulation played in the release of these enzymes. Most workers have concentrated on changes in serum glutamic oxaloacetic transaminase (GOT), although some have included other enzymes such as lactic dehydrogenase (LDH) and glutamic pyruvic transaminase (GPT). It has been shown that GOT increases after most surgical operations (Nickell and Allbritten, 1957; Lawrence and Schulkins, 1956; Craver, Johnson, and Beal, 1957; Person and Judge, 1958; Ticktin, Ostrow, and Evans, 1956; Di Carlo and Parisi, 1958; Candura and Minardi, 1957) but that this rise seldom exceeds 30 international units (i.u.) per litre. The greatest increases of GOT occurred after heart operations, especially after cardiovascular surgery with extracorporeal circulation (Baer and Blount, 1960; Snyder, Barnard, Varco, and Lillehei, 1958; Werle, Trautschold, Gorriz, and Zill, 1961 ; Quinn, Sirak, ${ }^{1}$ Correspondence to: Nora Welbourn, Nuffield Unit of Clinical Physiology, Dept. of Surgery, Postgraduate Medical School, Ducane Road, London, W.12.

'Present address: Department of Clinical Chemistry, Royal Infirmary, Edinburgh, 3.

Received for publication 27 October 1965 .
Shabanah, and Frajola, 1960; Pyörälä, Gord峞, Kontinnen, and Telivuo, 1963).

There is a wide divergence of opinion concerni $\vec{\nabla} g$ the reasons for these post-operative increase. Fraser, Rossall, Black, and Dvorkin (1962) a Quinn et al. (1960) suggest that the release of enzyme is due to surgical procedures which produce direct heart trauma. They show significantly higher G\&्g levels in cases having ventriculotomy than those without. Walker and Morgan (1964) and Baer and Blount (1960) were unable to confirm this conclusion. Snyder et al. (1958) suggest that hepatic changes occurring during perfusion are the major sources of increased levels of GOT, but Walker and Morgon (1964), Baer and Blount (1960), and Norberg andd Senning (1959) failed to verify this finding. It hod generally been assumed that increased serum enzyme activity was due to the release of enzymes from necrotic cells and, in particular, organs, until Hawss and Gerlach in 1958 advanced the concept of the acute syndrome. This proposed that GOT elevation was due to the complex response of the whAle organism rather than a local factor.

These conflicting results have led us to re-examige the problem and to broaden the study to inclufie LDH, GPT, hydroxybutyrate dehydrogenase (HBE), and isocitric dehydrogenase (ICD). Hydro\&ybutyrate dehydrogenase activity is associated mainy 
with the electrophoretically faster-moving fractions of LDH which occur predominantly in the myocardium (Rosalki and Wilkinson, 1960). This enzyme can be measured in the serum by a spectrophotometric method developed by Elliott and Wilkinson (1962). It has been shown to be a sensitive index of myocardial infarction (Elliott and Wilkinson, 1961; Elliott, Jepson, and Wilkinson, 1962; Hansson, Johansson, and Sievers, 1962; Konttinen, 1961; Konttinen and Halonen, 1963; Pagliaro and Notarbartolo, 1961) but at no time has it been found to rise in the serum without a concomitant increase in LDH (Wieme, 1962; Jontz, Bounous, Heimburger, Su, Teramoto, Shumacker, and Onnis, 1960; Rosalki and Wilkinson, 1960). Isocitric dehydrogenase is generally considered to reflect hepatic damage since a sharp increase in the serum activity follows liver cell damage, while normal values are obtained with myocardial infarction (White, 1958; Sterkel, Spencer, Wolfson, and WilliamsAshman, 1958; Sampson, 1958). However, Strandjord, Thomas, and White (1959) were able to demonstrate a transiently raised level of ICD during the first 24 hours after experimental myocardial infarction in dogs, thus showing that the damaged myocardium does release ICD. Its rapid disappearance from the circulation may account for failure to demonstrate increased levels following myocardial infarction.

\section{METHODS}

The patients studied were divided into two main groups. In the first group serum LDH, HBD, ICD, GOT, and GPT activities were measured in 22 patients preoperatively, immediately post-operatively, and thereafter daily, when possible, for two weeks to ascertain the general enzyme pattern following surgery. The patients in this group were further subdivided and the results analysed with respect to the following factors: age, type of operation, and length of perfusion.

In group II the variations in serum LDH, HBD, ICD, and GOT were followed intensively throughout the perfusion and immediate post-perfusion period in 12 patients. In order to assess the actual amount of enzyme released from the patient during perfusion it was necessary to take into account the dilution which occurred when the patient's blood was mixed with the priming volume in the heart-lung machine. This dilution varies with the patient's blood volume as the volume necessary to prime the oxygenator remains fairly constant.

The observed enzyme activity was corrected so as to reflect more accurately the true enzyme activity of the patient using the equation

$x=$

(observed enzyme activity

$\times$ total circulating volume)

(enzyme activity in pump patient's blood volume

when $x=$ the corrected enzyme activity.
All enzyme levels are expressed in i.u./litre and the blood volume is measured in litres.

This group was further subdivided in an attempt to see whether it was possible to detect increased serum enzyme activity during the perfusion period which could be attributed to myocardial damage. In order to do this, blood was simultaneously withdrawn from the coronary sinus, inferior vena cava, and oxygenator at the beginning and end of perfusion.

The operations were performed under mild hypothermia, and cardiopulmonary bypass was carried out using the Melrose-N.E.P. disc oxygenator (Melrose, 1961). The composition of the pump fluid generally consisted of 120 to $150 \mathrm{ml}$. of $4.2 \%$ sodium bicarbonate, 2.5 to 3 litres of whole blood, and $15 \mathrm{ml}$. per kilogram body weight of Rheomacrodex (Long, Sanchez, Varco, and Lillihei, 1961). The perfusion rate was maintained at 2.4 litres per sq. metre of body surface area per minute.

DETERMINATION OF ENZYME ACTIVITY Lactic dehydrogenase, HBD, ICD, GOT, and GPT were determined by the spectrophotometric methods described by Sigma using Sigma reagents. The results are expressed in international units (i.u.) per litre as recommended by the Joint Sub-Commission on Clinical Enzyme Units (King and Campbell, 1961) which defines 1 i.u. as the transformation of $1 \mu$ mole of substrate per minute. All measurements were corrected to $25^{\circ} \mathrm{C}$.

All the peak post-operative enzyme values expressed in this paper represent the highest level obtained within 72 hours after perfusion. This was necessary, even though the peak levels of GOT and ICD occurred within the first 24 to 48 hours, as the peak LDH and HBD activities often came within the 48- to 72-hour period.

COLLECTION OF BLOOD SPECIMENS All blood was withdrawn from the patient by venepuncture except during perfusion when samples were taken directly from the heart-lung machine. The serum was separated immediately and stored at $4^{\circ} \mathrm{C}$. All the estimations (with the exception of ICD which was measured within 24 hours) were completed in one week, during which time the results were reproducible within $\pm 1 \%$. Visibly haemolysed specimens were discarded since red blood cells contain appreciable amounts of LDH, HBD, ICD, and GOT, although Baer and Blount (1960) demonstrated that 80 to $100 \mathrm{mg}$. per $100 \mathrm{ml}$. of free haemoglobin did not significantly alter serum GOT levels. The special inferior vena cava and coronary sinus samples were taken by the surgeon at the operating table. The coronary sinus blood was taken by direct sampling from the right atrium immediately after the inferior and superior venae cavae had been snared and the systemic blood diverted, then just before the snares were released at the end of perfusion.

In one particular patient the hepatic veins did not join the inferior vena cava but entered the right atrium as a separate vessel. The hepatic vein was cannulated and samples withdrawn from it were compared with samples which had been drawn simultaneously from the coronary sinus. 
TABLE I

RELEVANT DATA AND PEAK POST-OPERATIVE ENZYME LEVELS OF THE 22 PATIENTS STUDIED IN GROUP I

\begin{tabular}{|c|c|c|c|c|c|c|c|c|c|c|}
\hline Diagnosis & $\operatorname{Sex}$ & Age & $\begin{array}{l}\text { Length of } \\
\text { Perfusion } \\
\text { (min.) }\end{array}$ & $\begin{array}{l}\text { Lowest } \\
\text { Temperature } \\
\left({ }^{\circ} \text { C.) on Bypass }\right.\end{array}$ & $\begin{array}{l}L D H \\
(75-240)\end{array}$ & $\begin{array}{l}H B D \\
(60-120)\end{array}$ & $\begin{array}{l}I C D \\
(0 \cdot 8-4 \cdot 4)\end{array}$ & $\begin{array}{l}\text { GOT } \\
(4-20)\end{array}$ & $\begin{array}{l}G P T \\
(2 \cdot 5-18\end{array}$ & 3) $\frac{\overrightarrow{\bar{\epsilon}}}{\overline{0}}$ \\
\hline Obstructive cardiomyopathy & Male & 43 & 76 & 25 & 178 & 131 & $4 \cdot 6$ & 66 & 23 & \\
\hline Subaortic stenosis & Male & 44 & 61 & 27 & 433 & 294 & $7 \cdot 1$ & 36 & 6 & \\
\hline Infundibular stenosis & Male & 57 & 82 & 27 & 420 & 502 & $7 \cdot 2$ & 80 & 17 & \\
\hline Mitral incompetence & Male & 23 & 133 & 27 & 523 & 322 & 4.9 & 58 & - & 르 \\
\hline Mitral incompetence & Female & 18 & 164 & 27 & 617 & 508 & $5 \cdot 9$ & 133 & - & עִ \\
\hline Aortic incompetence & Male & 48 & 176 & 24 & 292 & 371 & $6 \cdot 1$ & 53 & - & \\
\hline Mitral incompetence & Male & 45 & 354 & 27 & 525 & 345 & $7 \cdot 5$ & 67 & - & \\
\hline Ventricular septal defect & Male & $7 \frac{1}{2}$ & 61 & 19 & 565 & 313 & $12 \cdot 3$ & 109 & 33 & \\
\hline Ventricular septal defect & Female & 5 & 62 & 24 & 630 & 565 & $8 \cdot 2$ & 116 & 22 & \\
\hline Tetralogy of Fallot & Female & 10 & 64 & 21 & 275 & 266 & $6 \cdot \overline{2}$ & 64 & - & \\
\hline Atrioventricular canal & Male & $5 \frac{1}{2}$ & 71 & 23 & 414 & 268 & $6 \cdot 7$ & 79 & 12 & \\
\hline Tetralogy of Fallot & Female & 10 & 77 & 20 & 517 & 537 & $5 \cdot 4$ & 78 & 15 & \\
\hline Tetralogy of Fallot & Male & 12 & 79 & 23 & 689 & 490 & $5 \cdot 2$ & 110 & 26 & \\
\hline Ventricular septal defect & Female & 6 & 89 & 22 & 505 & 178 & 6.9 & 107 & 16 & \\
\hline Atrial septal defect & Male & 15 & 39 & 31 & 351 & 245 & 3.6 & 72 & 29 & \\
\hline pulmonary valvotomy & Male & 15 & 30 & 34 & 250 & 132 & $2 \cdot 4$ & 44 & - & \\
\hline Ventricular septal defect & Female & $10 \frac{1}{2}$ & 37 & 24 & 229 & 248 & $3 \cdot 7$ & 40 & 8 & \\
\hline Ventricular septal defect & Male & 6 & 40 & 26 & - & 246 & $5 \cdot 0$ & 61 & 11 & \\
\hline Atrial septal defect & Male & 15 & 41 & 34 & 263 & 234 & $3 \cdot 5$ & 55 & - & \\
\hline Traumatic ventricular septal d & & & & & & & & & & \\
\hline and aneurysm of left ventricle & Male & 10 & 44 & 24 & 250 & 164 & $4 \cdot 3$ & 42 & 9 & \\
\hline Atrial septal defect & Male & 39 & 53 & 31 & 262 & 199 & $3 \cdot 1$ & 55 & 14 & 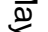 \\
\hline Ventricular septal defect & Male & 17 & 55 & 26 & 262 & 183 & $4 \cdot 6$ & 39 & 10 & \\
\hline
\end{tabular}

\section{RESULTS}

GROUP I The distribution of the patients in this group according to age, sex, type of operation, length of perfusion, and peak post-operative enzyme activity is shown in Table $I$.

The GPT results showed no consistent variations and as no significant conclusions could be drawn from them they are only shown in Table I and not discussed further.

\section{LOH}

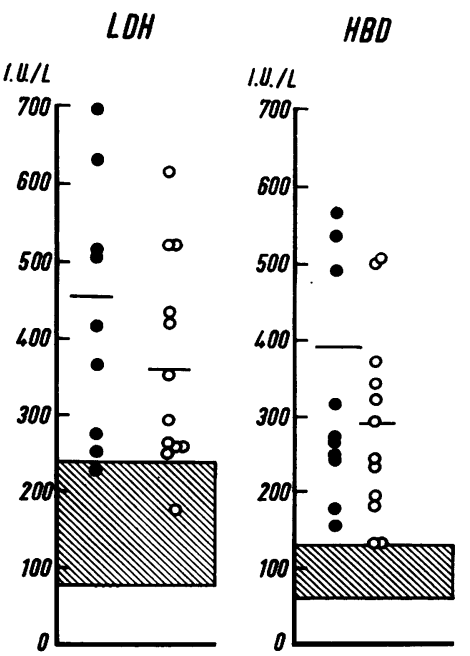

Children

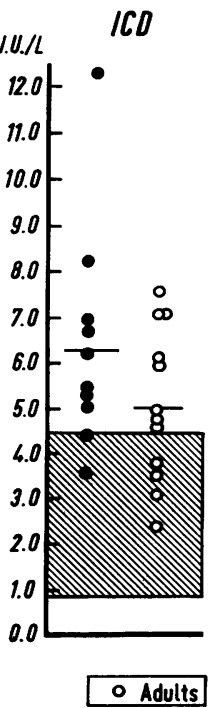

Effect of age Patients of 14 years of age aind above were considered as adults. The scatter aqd mean of peak post-operative enzyme levels for boin adults and children are shown in Figure 1. Theregis considerable overlapping in the individual perk post-operative levels of $\mathrm{LDH}, \mathrm{HBD}, \mathrm{ICD}$, and GOT between children and adults but the main peâk levels of all four enzymes are slightly higher children.

Type of operation In considering the effects
GOT

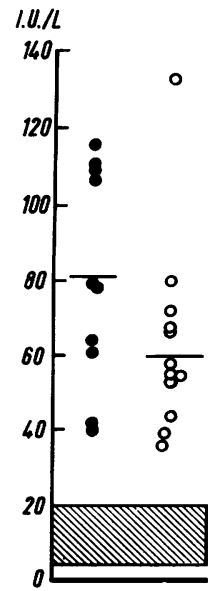

FIG. 1. Peak post-operative enzym levels. Mean values shown by horizontal lines; normal range shaded.
官 

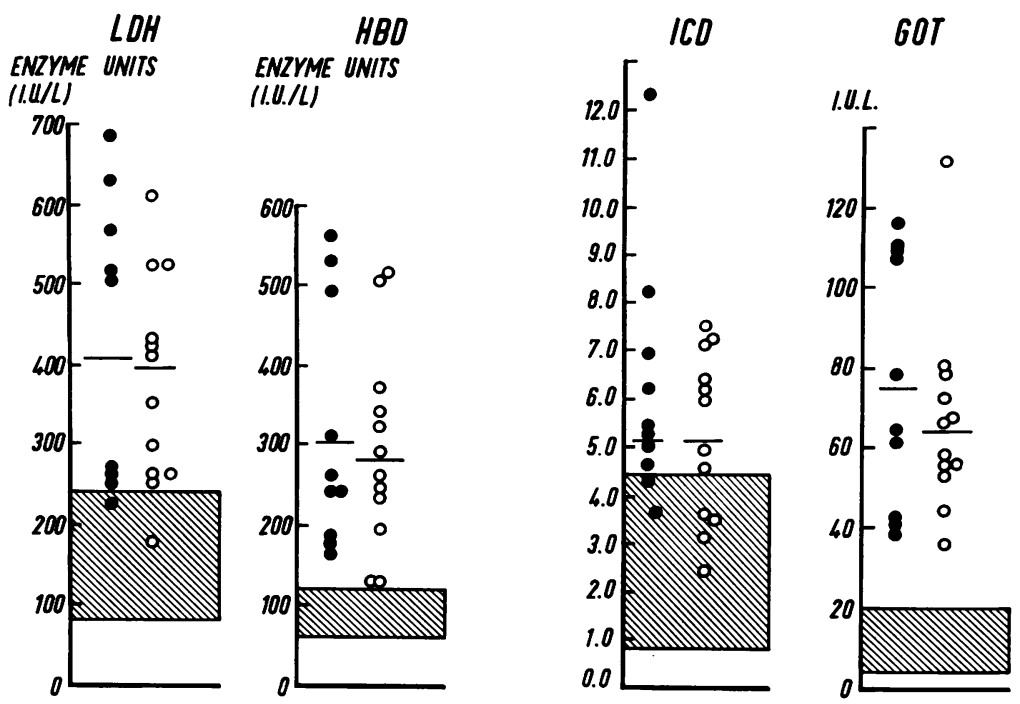

FIG. 2. Peak post-operative enzyme levels in patients undergoing cardiac surgery with ventriculotomy (O) and without ventriculotomy $(\bigcirc)$. Mean values shown by horizontal lines: normal ranges shaded. surgical trauma the patients were subdivided according to those having ventriculotomy (10 patients) and those not having ventriculotomy (12 patients). The patients having ventriculotomy included the following cases: ventricular septal defect (7 cases), tetralogy of Fallot (3), subaortic stenosis (1), obstructive cardiomyopathy (1), and those without ventriculotomy included atrial septal defect (4), mitral incompetence (3), aortic incompetence (1), infundibular stenosis (1), and atrioventricular canal (1). In Fig. 2 the scatter and mean peak post-operative levels between the two groups are indicated. These results indicate that incision of the right ventricle alone cannot account for the main increases observed following perfusion as there are no significant differences between the two groups.

Length of perfusion The patients were then subdivided according to the length of perfusion with the division arbitrarily chosen as one hour. Group A consists of the 14 cases perfused for over one hour and group $B$ of the eight perfused for under one hour. In Fig. 3 each patient's daily enzyme level is indicated as well as the mean daily levels for groups A and B. From examining these results it can be seen that although the pre-operative levels are equal for both $A$ and $B$, there are significant differences between their post-operative levels. The average peak levels of LDH, HBD, and GOT are approximately twice

TABLE II

MEAN PEAK POST-OPERATIVE ENZYME LEVELS BETWEEN CHILDREN AND ADULTS PERFUSED FOR UNDER AND OVER ONE HOUR

\begin{tabular}{|c|c|c|c|c|c|c|}
\hline \multirow[t]{2}{*}{ Group } & \multirow{2}{*}{$\begin{array}{l}\text { Division by Age (adults over } 14 \text { yr. } \\
\text { and children under } 14 \text { yr.) }\end{array}$} & \multirow{2}{*}{$\begin{array}{l}\text { No. of } \\
\text { Cases }\end{array}$} & \multicolumn{4}{|c|}{ Average Peak Serum Enzyme Levels } \\
\hline & & & $\begin{array}{l}L D H \\
(75-240)\end{array}$ & $\begin{array}{l}H B D \\
(60-120)\end{array}$ & $\begin{array}{l}I C D \\
(0 \cdot 8-4 \cdot 4)\end{array}$ & $\begin{array}{l}G O T \\
(4-20)\end{array}$ \\
\hline $\begin{array}{l}\text { A (perfused for over one hour) } \\
\text { B (perfused for under one hour) }\end{array}$ & $\begin{array}{l}\text { Children } \\
\text { Adults } \\
\text { Children } \\
\text { Adults }\end{array}$ & $\begin{array}{l}7 \\
8 \\
3 \\
5\end{array}$ & $\begin{array}{l}514 \\
427 \\
256 \\
258\end{array}$ & $\begin{array}{l}373 \\
335 \\
202 \\
189\end{array}$ & $\begin{array}{l}6 \cdot 6 \\
5 \cdot 3 \\
4 \cdot 0 \\
3 \cdot 4\end{array}$ & $\begin{array}{l}95 \\
65 \\
49 \\
53\end{array}$ \\
\hline
\end{tabular}

TABLE III

MEAN PEAK POST-OPERATIVE ENZYME LEVELS BETWEEN PATIENTS WITH AND WITHOUT VENTRICULOTOMY PERFUSED FOR UNDER AND OVER ONE HOUR

Group

Type of Operation

No. of

Average Peak Serum Enzyme Levels

Cases $L D H \quad H B D \quad I C D \quad G O T$

$\begin{array}{llll}L D H & H B D & T C D & G O T \\ (75-240) & (60-120) & (0 \cdot 8-4 \cdot 4) & (4-20)\end{array}$

\begin{tabular}{ll}
\hline A (perfused for over one hour) & Ventriculotomy \\
& No ventriculotomy \\
B (perfused for under one hour) & Ventriculotomy \\
& No ventriculotomy
\end{tabular}

$\begin{array}{lllll}6 & 547 & 389 & 5 \cdot 9 & 97 \\ 8 & 425 & 348 & 5 \cdot 8 & 65 \\ 4 & 225 & 196 & 4 \cdot 1 & 45 \\ 4 & 251 & 212 & 4 \cdot 1 & 46\end{array}$


as high in A, and, with the exception of two cases, only those patients perfused for over one hour have peak ICD levels outside the normal limit.

Since perfusion time is clearly an important factor affecting post-operative enzyme levels, groups A and $B$ were examined separately to consider whether age or ventriculotomy affected the results when this source of variation was eliminated. From the results (Tables II and III) it is obvious that neither factor plays a determining role in affecting the mean peak enzyme levels in the group perfused for under one hour, but in the group perfused for over one hour the peak levels of LDH, HBD, and GOT are slightly higher in children and patients having ventriculotomy.

GROUP II In this part of the study an attempt was made to determine the actual amount of enzyme released from the patient during perfusion. This assessment was necessary to determine the dilution which occurred when the patient's blood was mix with the priming fluid of the heart-lung machine.

As care was taken to choose patients having lit我 or no visible haemolysis, the increased enzynge activity in the oxygenator after perfusion (Table IY) cannot be attributed to haemolysis and therefore must represent cellular enzymes which have bee released from the patient during perfusion.

By substituting the volumes given in Table $\mathrm{V} \stackrel{\text { m }}{0}$ the formula (described under methods) correctio $\overrightarrow{D S}$ were calculated for 12 patients. The observed and corrected values for five patients are shown. Figures 4-8. From examining these results it can seen that without correction the enzyme activities determined in the first sample taken after just going on perfusion are actually lower than the pres perfusion levels in most cases, whereas if correctod there is an immediate increase. It is also apparegt that without correction the serum enzyme activify determined immediately after perfusion is often only

TABLE IV

AVERAGE SERUM ENZYME LEVELS PRESENT IN THE HEART-LUNG MACHINE BEFORE AND AFTER PERFUSION

\begin{tabular}{|c|c|c|c|c|c|}
\hline \multirow[t]{2}{*}{ No. of Cases } & \multirow{2}{*}{$\begin{array}{l}\text { Serum Enzyme Levels in the } \\
\text { Heart-lung Machine }\end{array}$} & \multicolumn{4}{|c|}{ Average Oxygenator Serum Enzyme Levels } \\
\hline & & $\begin{array}{l}L D H \\
(75-240)\end{array}$ & $\begin{array}{l}H B D \\
(60-120)\end{array}$ & $\begin{array}{l}I C D \\
(0 \cdot 8-4 \cdot 4)\end{array}$ & $\begin{array}{l}G O T \\
(4-20)\end{array}$ \\
\hline 15 & $\begin{array}{l}\text { Before perfusion } \\
\text { After perfusion }\end{array}$ & $\begin{array}{l}157 \\
276\end{array}$ & $\begin{array}{r}80 \\
153\end{array}$ & $\begin{array}{l}0.3 \\
2.5\end{array}$ & $\begin{array}{l}10 \\
29\end{array}$ \\
\hline
\end{tabular}

TABLE V

RELEVANT DATA FOR PATIENTS IN GROUP II FROM WHICH THE DILUTION FACTOR WAS CALCULATED FOR CORRECTED AND UNCORRECTED ENZYME LEVELS SHOWN IN FIGURES 4 TO 8

\begin{tabular}{ll} 
Case No. & Age and Sex \\
& \\
\hline 1 & 44 Male \\
2 & 58 Male \\
3 & 39 Male \\
4 & 53 Male \\
5 & 13 Female
\end{tabular}

Diagnosis

Subaortic stenosis

Aortic valve replacement

Aortic valve replacement

Aortic valve replacement

Fallot's tetralogy
Length of Perfusion

(min.)

60

60
132

132
80

93

83
Patient's

Blood Volume

(l.)

3.6

$3 \cdot 6$
$4 \cdot 54$

5.06

$5 \cdot 12$

3.3

TABLE VI

\begin{tabular}{|c|c|c|c|c|}
\hline $\begin{array}{l}\text { Case } \\
\text { No. }\end{array}$ & $\begin{array}{l}\text { Age and } \\
\text { Sex }\end{array}$ & Diagnosis & $\begin{array}{l}\text { Perfusion } \\
\text { Time } \\
\text { (min.) }\end{array}$ & Blood Specimen \\
\hline
\end{tabular}

$5 \quad 13$ Female Fallot's tetralogy

Coronary sinus Inferior vena cava Oxygenator Coronary sinus

$6 \quad 29$ Male $\quad$ Ventricular septal defect $\quad 83$ Inferior vena cava Oxygenator Coronary sinus Inferior vena cava Oxygenator Coronary sinus

$8 \quad 14$ Female Ventricular septal defect 47

Inferior vena cava Oxygenator Coronary sinus Inferior vena cava Oxygenator 
$\angle O H$
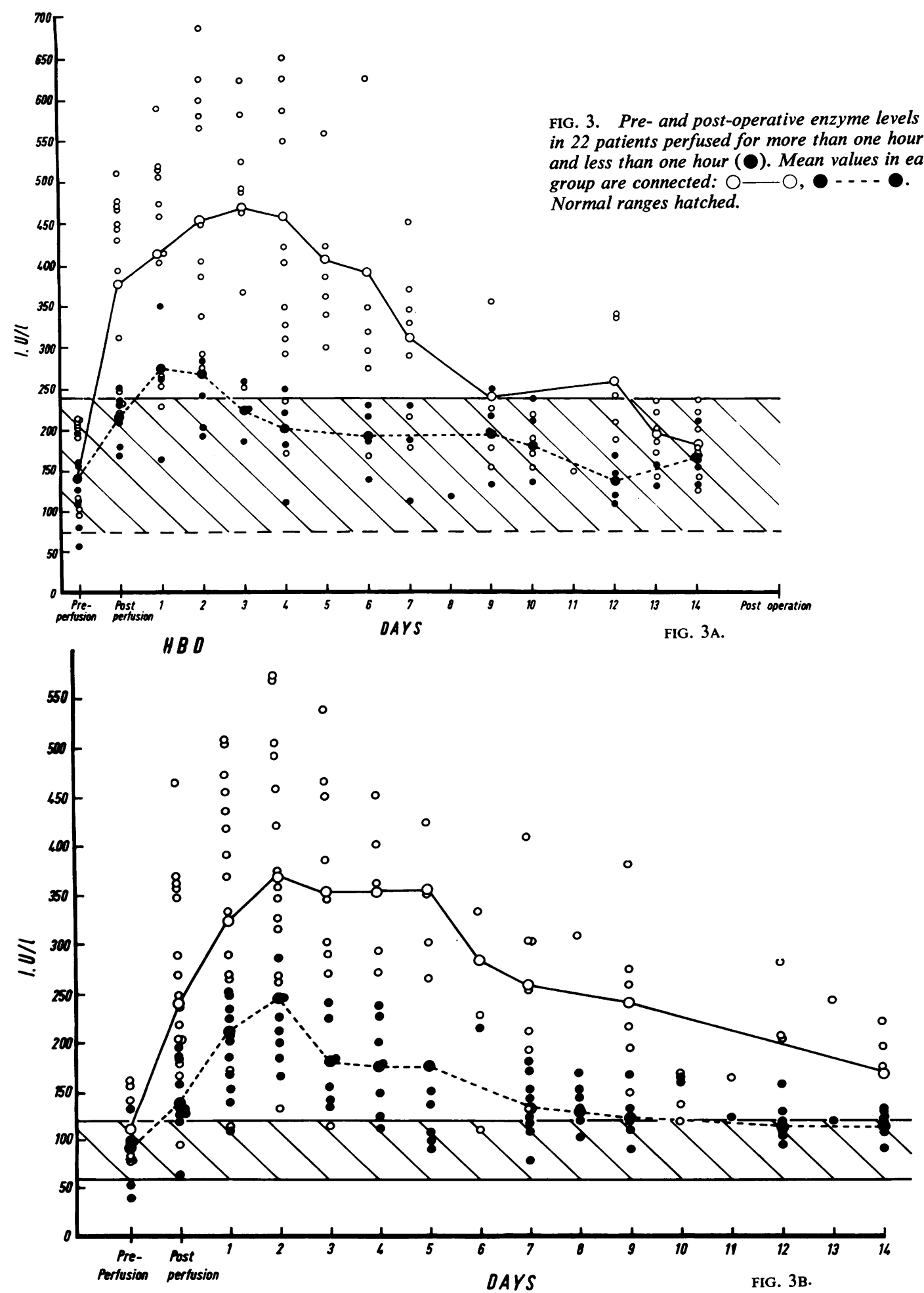
in 22 patients perfused for more than one hour $(O)$ and less than one hour (๑). Mean values in each group are connected: $\bigcirc-\bigcirc, 0$-... 

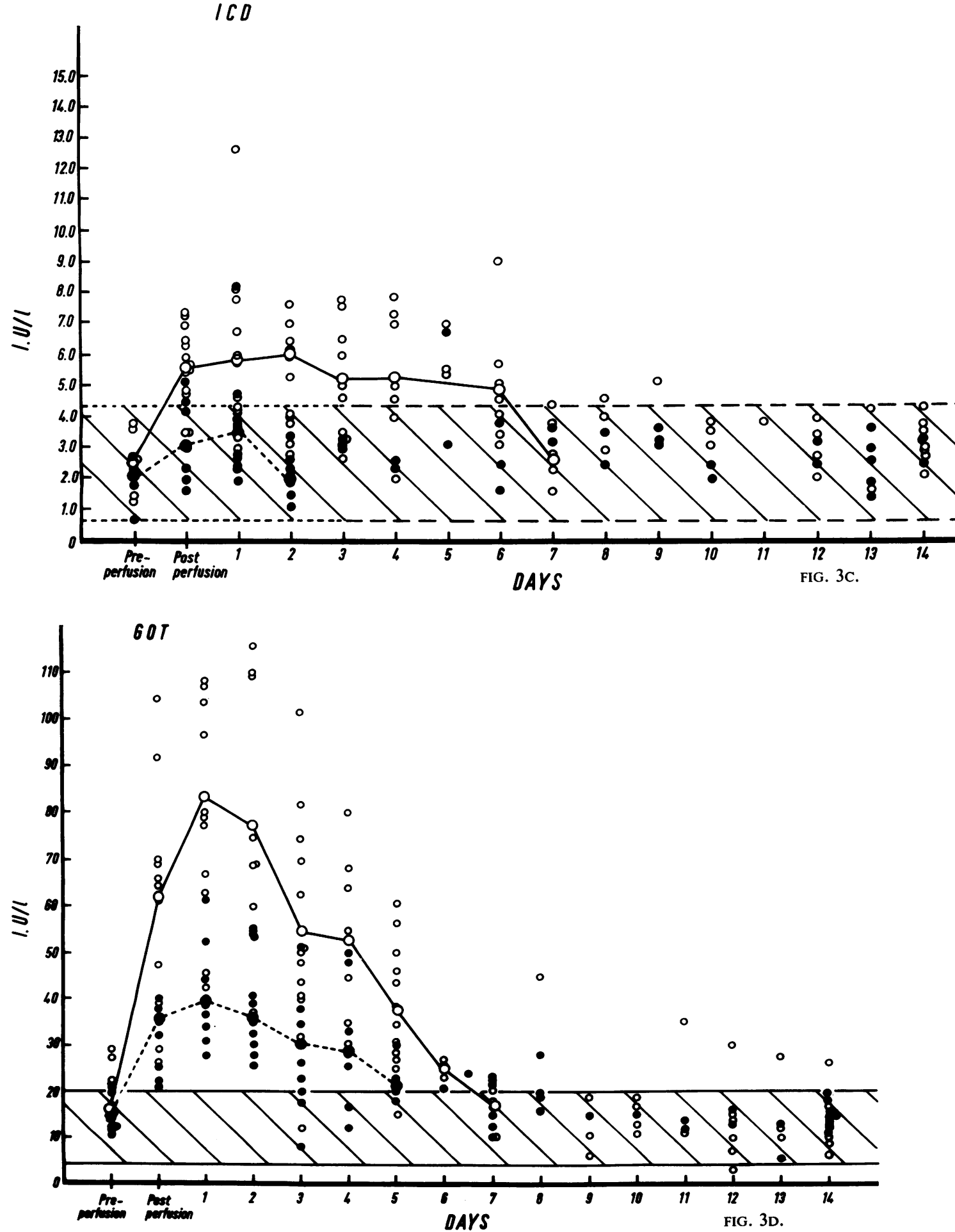
CASE 1
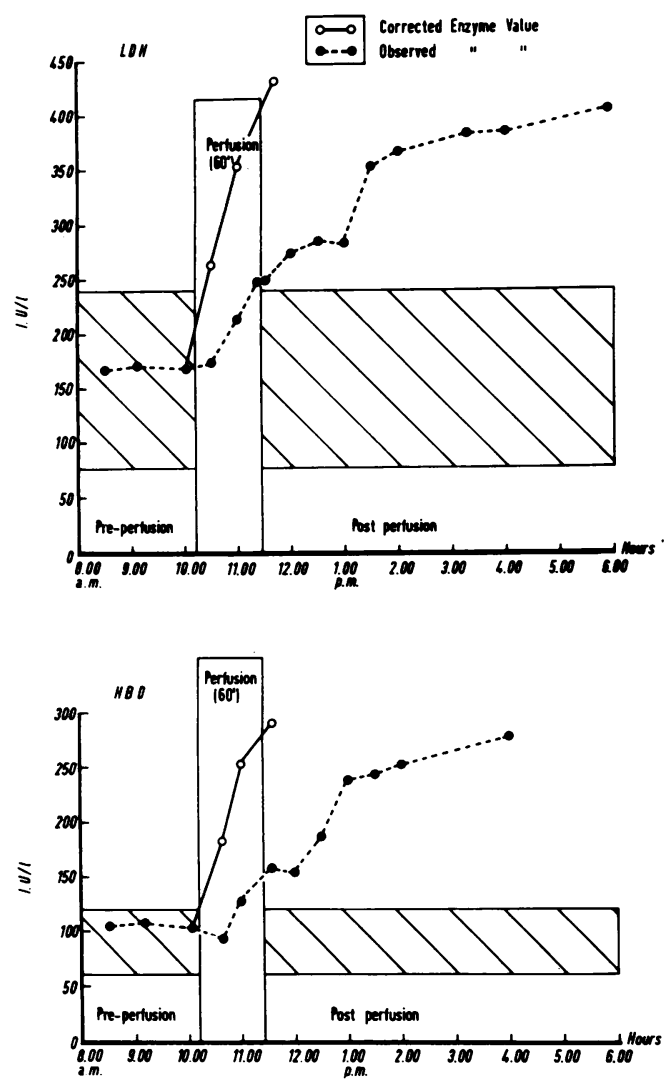

FIG. 4A.
CASE 1
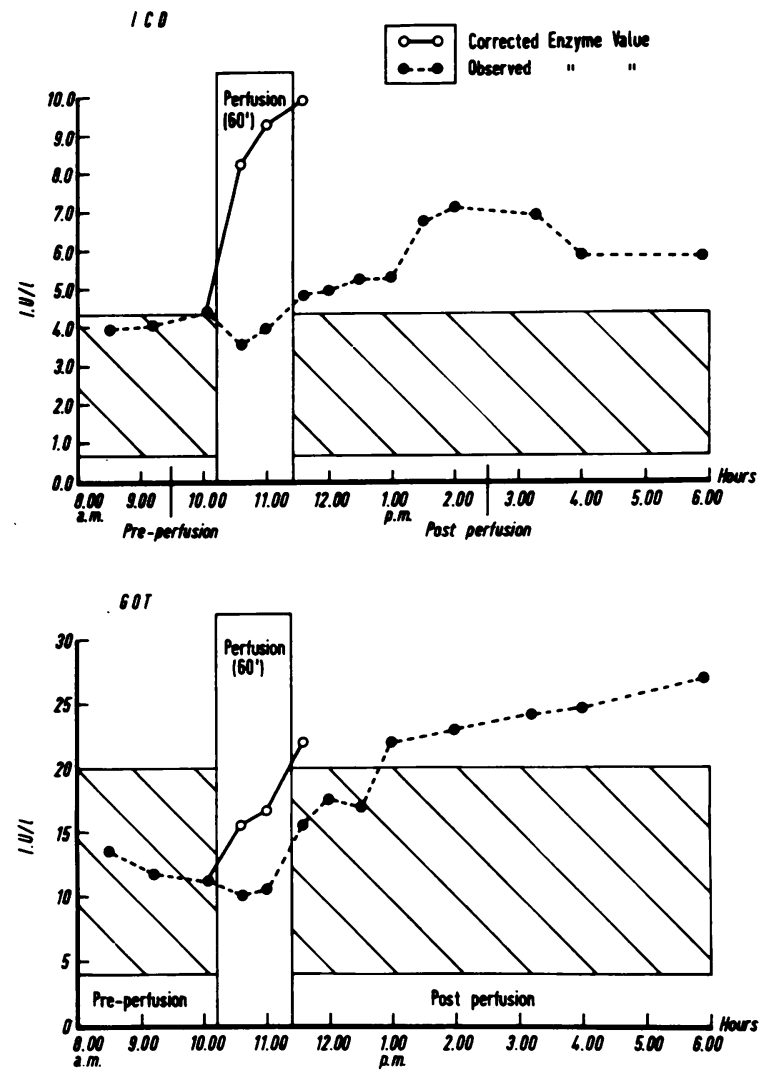

FIG. 4B.

FIGS. 4-8. Enzyme levels during perfusion, with and without correction for priming volume of oxygenator. Normal ranges hatched.

slightly increased above the pre-operative level, whereas when the dilution is corrected for, these results become significantly raised by 30 to $50 \%$.

In Table VI, the results are shown of the study which attempted to see if myocardial damage could be reflected in the serum enzyme activity of blood taken from the coronary sinus as opposed to either the inferior vena cava or the oxygenator. Only with HBD are there any consistent differences between the coronary sinus and inferior vena cava samples. All five patients have higher HBD activity in the coronary sinus sample at the end of perfusion.

In the one case in which the hepatic vein entered the right atrium directly, the post-operative ICD levels exceeded normal, and therefore if the liver were the main source of ICD one would expect to observe a higher enzyme activity in the specimen from the hepatic vein. In actual fact the ICD activity was higher in the coronary sinus samples.

One significant point to emerge from this particular study is that in most cases the enzyme activities at the end of perfusion were higher in the samples from the patient than from the oxygenator. This indicates that the main increase in enzyme activity is due to the release of cellular enzymes from the patient's tissues and thus emphasizes the importance of considering the dilution factor when assessing damage to the patient during perfusion.

\section{DISCUSSION}

The results in group I show that the length of perfusion plays a major role in determining the amount of increased enzyme activity following 

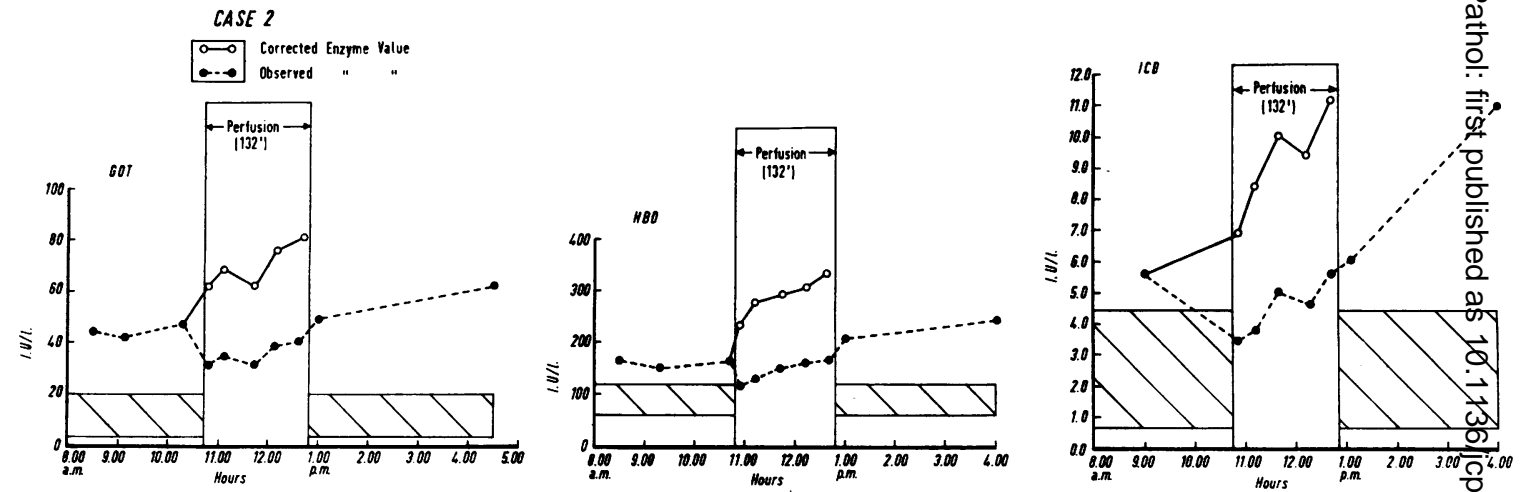

\section{CASE 3}

FIG. 5 .
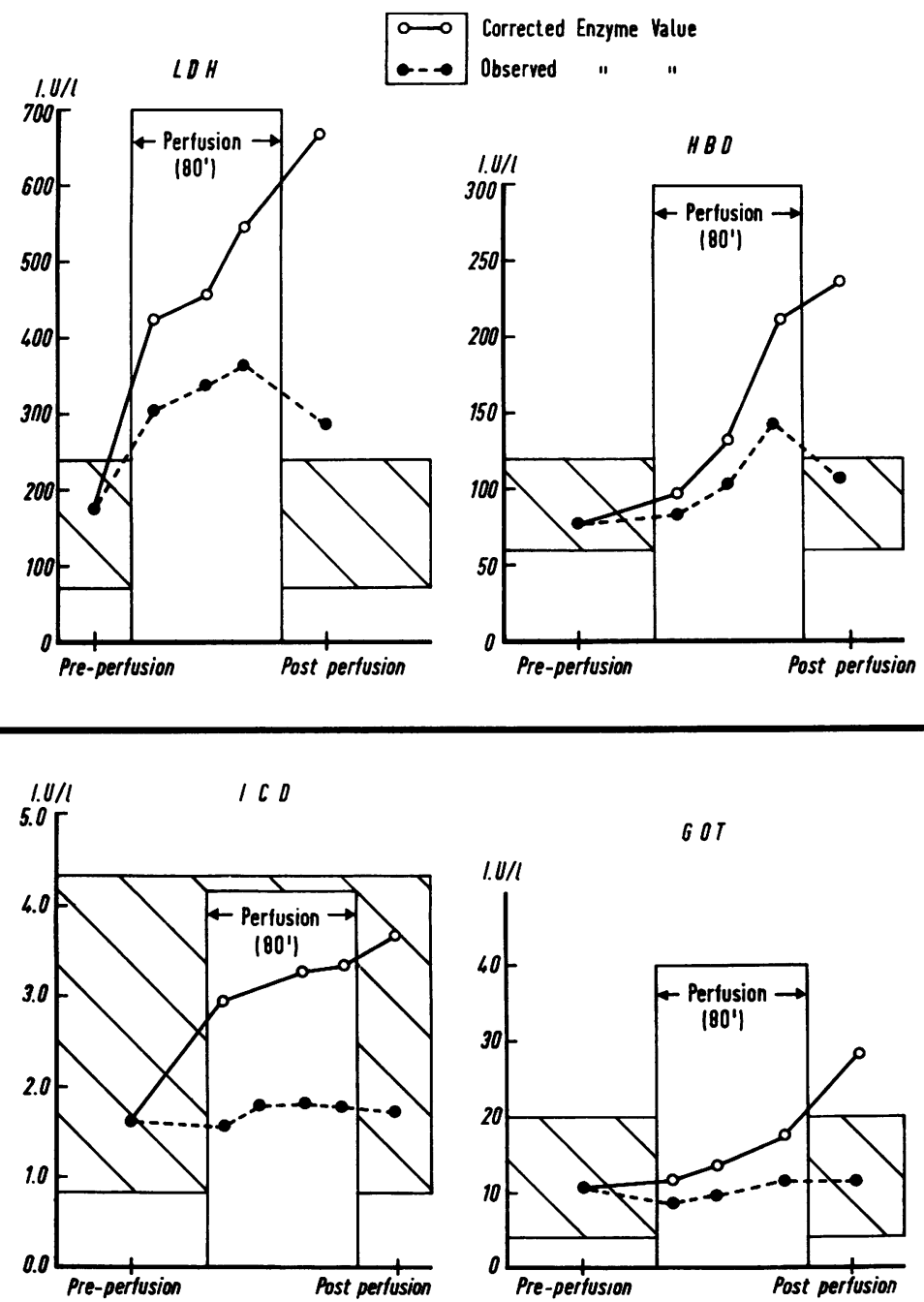

FIG. 6. 
CASE 4
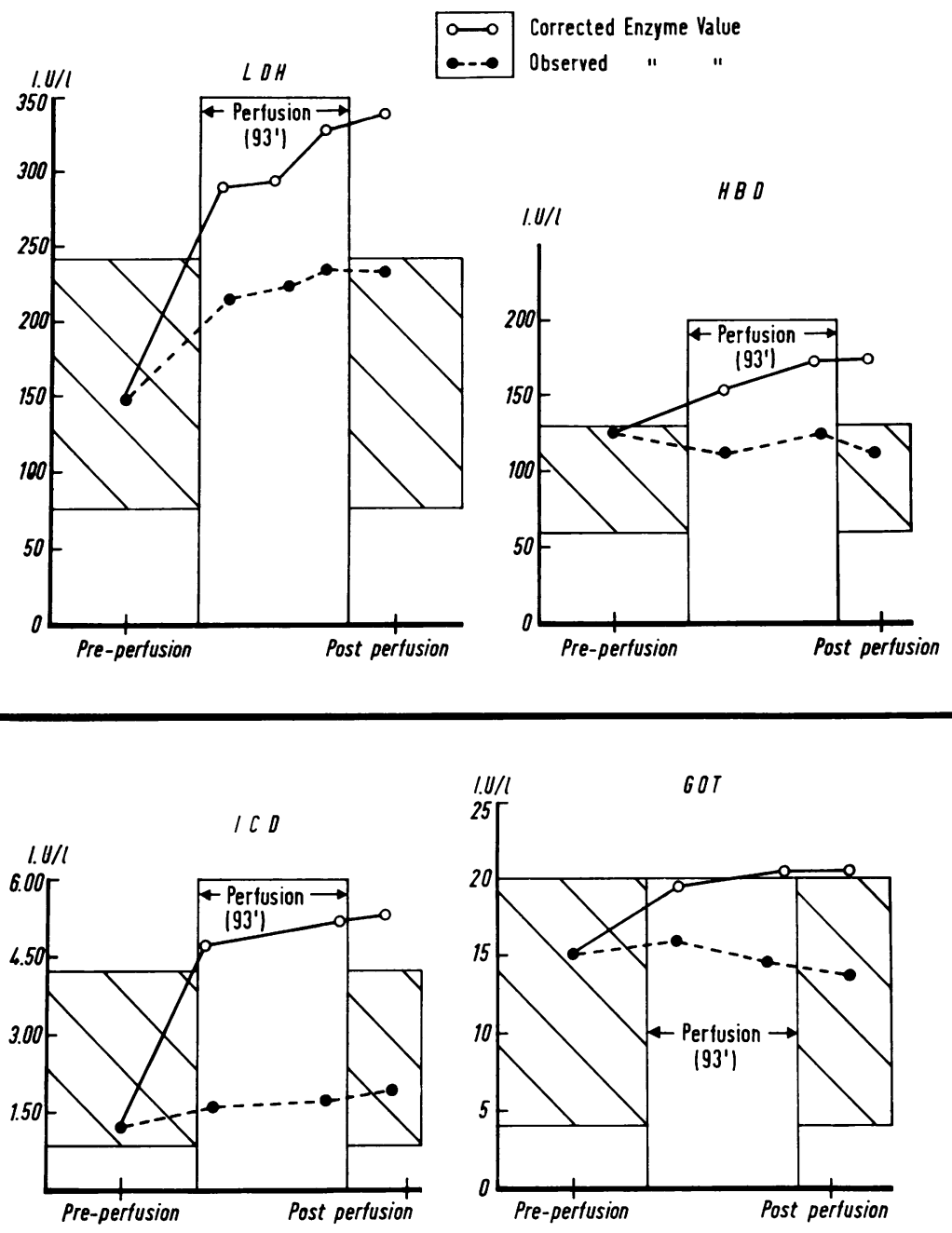

FIG. 7.

cardiac surgery with perfusion, the mean postoperative peak levels of LDH, HBD, ICD, and GOT being significantly higher in the group perfused for over one hour. An effect due to age or ventriculotomy could be established only in the group perfused for over one hour. The mean peak levels of $\mathrm{LDH}$, HBD, and GOT were then seen to be slightly higher in cases having ventriculotomy, and although both adults and children had higher enzyme activities when perfused for over an hour, the levels for children were increased above the normal limits by approximately $30 \%$ more than those for adults.

Hepatocellular damage was not considered to be a major source of increased enzyme activity, and the increased ICD activity could not be attributed solely to liver damage, as was shown by the one case in which there was abnormality of the hepatic veins. Campbell and Moss (1962) have shown that in the heart the predominating fraction of ICD is extremely labile whereas that of liver ICD is more stable; this could account for the difficulty in demonstrating increased ICD activity following myocardial infarction. In all our cases perfusion was carried out under mild hypothermia, so that ICD being released from the myocardium during perfusion would be more likely to be detected.

The results in group I demonstrate the importance of the duration of the perfusion period in influencing 


\section{CASE 5}

$\because$ Corrected Enzyme Value
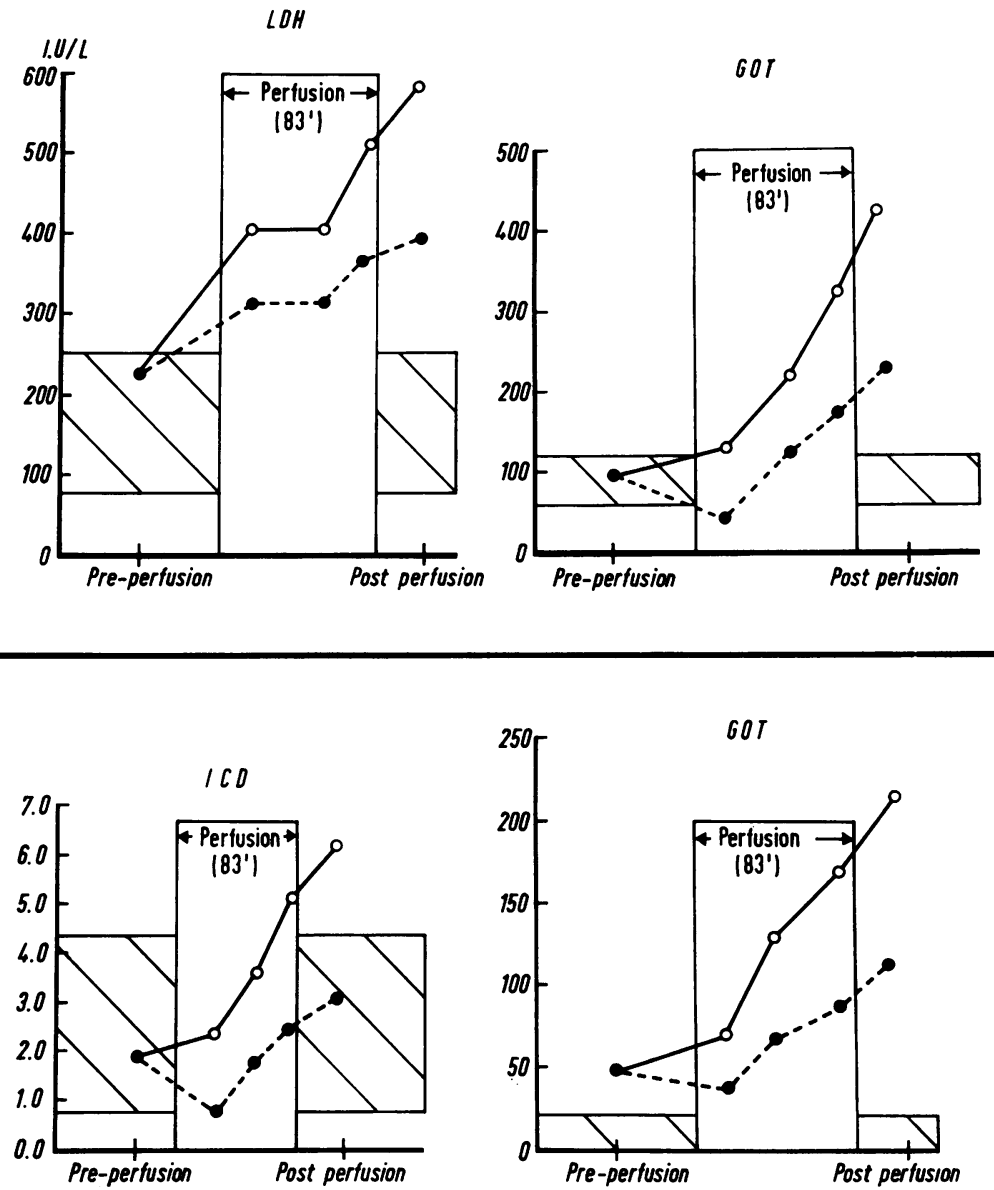

FIG. 8.

the post-perfusion serum enzyme levels; therefore, in group II this period was studied in greater detail. The activities of all the enzymes studied increased during perfusion, and when corrected for dilution the majority of them exceeded the normal limits by the end of perfusion. Dilution by the oxygenator priming volume conceals this rapid rise in enzyme levels taking place during perfusion; the corrected levels are some 30 to $50 \%$ higher than the measured values, and emphasize the importance of perfusion as the factor which causes enzyme release from the tissues.

When the enzyme activity remaining in the oxygenator after perfusion was compared with the pre-perfusion level, a marked increase was observe ${ }_{\sigma}$. Undoubtedly some of this came from haemolys produced by the pump, but by choosing cases to follow with little or no haemolysis at the end of perfusion, this factor could be ignored, and the ins creased enzyme activity in the oxygenator at the end of perfusion could be attributed mainly to release of enzymes from the patient's tissues. When bleeding extensive in the immediate post-perfusion period it is extremely difficult to assess the actual increases ienzyme activity in the patient as the blood volume $\overrightarrow{10}$ kept constant by replacement of losses with whole blood or plasma; thus, blood with elevated enzyme activity is being replaced by blood with a low 
enzyme activity. The amount of enzyme activity lost cannot be accurately accounted for because the blood lost is removed by high-pressure suction which haemolyses it severely.

The results of other workers in this field are extremely diverse. Quinn et al. (1960), Snyder et al. (1958), and Fraser et al. (1962) demonstrated higher peak GOT levels in cases with ventriculotomy. Norberg and Senning (1959) noted increases of HBD as well as of GOT following ventriculotomy. In group I of this study, although the highest single HBD, LDH, and GOT levels occurred in patients with a ventricular incision, no correlation could be drawn in general between the mean peak enzyme levels and the degree of surgical trauma. This is corroborated by Baer and Blount (1960), who analysed their results statistically and could show no significant differences between Fallot operations, ventricular septal defects approached via the ventricle, and ventricular septal defects with an atrio-ventriculoris communis defect approached via the auricle. Walker and Morgan (1964) also were unable to demonstrate significant differences in the peak GOT levels between cases with and without ventriculotomy. If an increase in GOT were related to the extent of surgical trauma then one would expect to demonstrate higher GOT levels with thoracotomies than with laparotomies. Neither our results nor those of Pyörälä et al. (1963), Quinn et al. (1960), and Werle et al. (1961) showed a difference between them.

Nyhus (1958) states that in his experiments the isolated liver tolerated perfusion poorly, developing severe oedema. Snyder et al. (1958) suggest that extracorporeal circulation might subject the liver to reduced oxygenation, or cause sufficient congestion to produce permeability changes in the cell membrane and allow enzymes to leak out. If this were a major source of increased enzymes, GPT would be expected to increase. We could not demonstrate significant changes in GPT, in agreement with the experience of Walker and Morgan (1964), Baer and Blount (1960), Pyörälä et al. (1963), and Norberg and Senning (1959). The last authors also measured serum ornithine carbamyl transferase, which is a more sensitive index of liver damage than the transaminases, and were unable to demonstrate significant changes in its activity post-operatively. Bang, Iversen, Jagt, and Tobiassen (1959) showed that GOT increases could come from centrilobular necrosis following acute heart failure superimposed upon chronic heart failure, but Baer and Blount (1960) were unable to show histological evidence of centrilobular necrosis in the livers of patients who died in the immediate post-operative period. They suggest that the chemical changes may precede the anatomical changes and agree with the concept of 'acute syndrome' as put forward by Hauss and Gerlach (1958), which regards the release of enzyme as due to an overall response of the organism rather than to a single factor. Pyörälä et al. (1963) and Werle et al. (1961) also support this idea.

Baer and Blount (1960) observed a positive correlation between the post-operative enzyme levels and the duration of cardiopulmonary bypass. They found that the GOT levels were significantly higher in cases perfused for over 40 minutes. Fraser et al. (1962) and Pyörälä et al. (1963) were able to correlate post-operative enzyme activity with the length of perfusion only in cases having ventriculotomy. Snyder et al. (1958), Quinn et al. (1960), and Werle et al. (1961) suggest that no correlation exists between the post-operative enzyme levels and the duration of cardiopulmonary bypass. The failure of other workers to demonstrate such a correlation could be accounted for by the fact that the few investigators who studied the perfusion period did not consider the dilution from the priming fluid of the heart-lung machine to be relevant.

Other factors have been considered as possible causes for increasing enzyme activities. Lawrence and Schulkins (1956) found that the type of anaesthetic did not influence the post-operative GOT levels following surgical operations; March, Greenberg, and Rinehart (1954) demonstrated that haemolysis increased the enzyme levels; Crafoord, Norberg, and Senning (1957) found that, with seven to 59 minutes on bypass, the haemolysis values did not exceed 15 to $55 \mathrm{mg}$. haemoglobin/100 ml. of plasma, while Baer and Blount (1960) showed that 80 to $100 \mathrm{mg}$. per $100 \mathrm{ml}$. of free haemoglobin in haemolysed samples did not significantly alter GOT levels. Fraser et al. (1962) found that the postoperative GOT levels in children were considerably higher than in adults. Werle et al. (1961) were unable to correlate the increased enzyme activity with any of the following factors: type of operation, length of perfusion, hypothermia, type of anaesthetic, or age.

When these results are considered together it appears that the increased enzyme activities following cardiac surgery with extracorporeal circulation reflect the response of the whole organism to the perfusion. Increased activities do occur when cardiac surgery is performed without perfusion but to a lesser extent. The difference is even more impressive if corrections are applied for the dilution from the priming fluid of the heart-lung machine. The raised enzyme activity probably results from an increased permeability of cellular membranes, thus allowing the intracellular contents to enter the circulation. These changes could result from any of the following: variation in $p \mathrm{H}$, lowered substrate levels, decreased 
oxidative phosphorylation, anoxia occurring from decreased peripheral circulation and exclusion of certain vessels due to the reversed blood flow during perfusion, and collapse of small vessels from hypothermia.

In assessing our results we feel that although the release of cellular enzymes cannot be attributed to a single source a large proportion of them are coming from myocardial tissue. This can be seen from examining the HBD results for the patients perfused for over one hour in group I (Fig. 3). The mean level of HBD was still raised above normal after two weeks whereas the other three enzymes studied were generally within normal limits after one week. As increased HBD activity is indicative of myocardial damage, this can be taken as a sign that the heart is not fully recovered and is still releasing enzymes into the circulation from damaged cells.

\section{REFERENCES}

Baer, H., and Blount, S. G., Jr. (1960). The response of the serum glutamic oxaloacetic transaminase to open-heart operations. Amer. Heart J., 60, 867.

Bang, N. U., Iversen, K., Jagt, T., and Tobiassen, G. (1959). Serum glutamic-oxaloacetic transaminase activity as an index of centrilobular liver cell necrosis in cardiac and circulatory failure. Acta med. scand., 164, 385.

Campbell, D. M., and Moss, D. W. (1962). Some properties of human isocitric dehydrogenase isoenzymes. Proc. Ass. clin. Biochem., $2,10$.

Candura, F., and Minardi, C. (1957). Sul comportamento della transaminasi gluttammico-ossalacetica sierica in pazienti sottoposti a interventi chirurgici $e$ in soggetti traumatizzati. Minerva chir., 12, 1077.

Crafoord, C., Norberg, B., and Senning, A. (1957). Clinical studies in extracorporeal circulation with a heart-lung machine. Acta chir. scand., 112, 220.

Craver, W. L., Johnson, G., Jr., and Beal, J. M. (1957). Alterations in serum glutamic-oxaloacetic transaminase activity following operations. Surg. Forum, 8, 77.

Di Carlo, G., and Parisi, A. (1958). Modificazioni dell'attivita transaminascia nel decorso post-operatorio e suo significato. Rif. med., 71, 1275.

Elliott, B. A., and Wilkinson, J. H. (1961). Serum 'alpha-hydroxybutyric dehydrogenase' in myocardial infarction and liver disease. Lancet, 1, 698.

- - (1962). The relative efficiencies of some serum-enzyme tests in the diagnosis of myocardial infarction. Ibid., 2, 71.

—, Jepson, E. M., and Wilkinson, J. H. (1962). Serum alphahydroxybutyrate dehydrogenase-a new test with improved specificity for myocardial lesions. Clin. Sci., 23, 305.

Fraser, R. S., Rossall, R. E., Black, W., and Dvorkin, J. (1962). Serum transaminase response to cardiac surgery using cardiopulmonary bypass. $J$. thorac. cardiovasc. Surg., 43, 810.

Hauss, W., and Gerlach, U., and Schurmeyer, E. (1958). Uber die Pathogenese und die Klinische Bedeutung der Hyperfermentämie. Dtsch. med. Wschr., 83, 1310.

Hansson, A., Johansson, B., and Sievers, J. (1962). Serum 'alphahydroxybutyric dehydrogenase' in myocardial infarction and in liver disease. Lancet, 1, 167.
Jontz, J., Bounous, G., Heimburger, I., Su, C. S., Teramoto, \& Shumacker, H. B., Jr., and Onnis, M. (1960). Renal and por鸟1 blood flow under normothermic and hypothermic conditions during extracorporeal circulation. J. thorac. cardiovasc. Sur 离, $39,781$.

King, E. J., and Campbell, D. M. (1961). International enzyme units: an attempt at international agreement. Clin. chim. Acta, 6, 30if.

Konttinen, A. (1961). Alpha-hydroxybutyric dehydrogenase in the detection of myocardial infarction. Lancet, $2,556$.

and Halonen, P. I. (1963). Serum creatine phosphokinase ap alpha-hydroxybutyric dehydrogenase activities compared wit GOT and LDH in myocardial infarction. Cardiologia (Based), $43,56$.

Lawrence, S. H., and Schulkins, T. H. (1956). Serum transaminase levels following prolonged surgical anaesthesia. Anesthesiology, $17,531$.

Long, D. M., Jr., Sanchez, L., Varco, R. L., and Lillihei, C. $\overline{\mathrm{W}}$ (1961). The use of low molecular weight dextran and seru间 albumin as plasma expanders in extracorporeal circulatio Surgery, 50, 12.

March, M. E., Greenberg, L. D., and Rinehart, J. F. (1954). Trangt aminase activity of blood hemolysates. Fed. Proc., 13, 467..

Melrose, D. G. (1961). Types of heart-lung machines used in extfat corporeal circulation. Postgrad. med. J., 37, 639.

Nickell, W. K., and Allbritten, F. F., Jr. (1957). Serum transaminase content related to tissue injury. Surgery, 42, 240.

Norberg, B., and Senning, $\mathbb{A}$. (1959). A study of serum enzyme during and after surgery with the Crafoord-Senning heart-lung machine. Acta chir. scand., suppl., 245, 275.

Nyhus, L. (1958). Quoted in Extracorporeal Circulation, edited J. G. Allen, p. 226. Thomas, Springfield, III.

Pagliaro, L., and Notarbartolo, A. (1961). Alpha-hydroxybutyrit dehydrogenase in the detection of myocardial infarctiog Lancet, 2, 1261.

Person, D. A., and Judge, R. D. (1958). Effect of operation on tranisaminase levels. Arch. Surg., 77, 892.

Pyörälä, K., Gordin, R., Kontinnen, A., and Telivuo, L. (19633 Serum enzymes after cardiac surgery. Acta med. scand., 13 , 361 .

Quinn, J. W., Sirak, H. D., Shabanah, E. H., and Frajola, W. (1960). Transaminase values following open-heart surget Ann. Surg., 152, 45.

Rosalki, S. B., and Wilkinson, J. H. (1960). Reduction of alplet ketobutyrate by human serum. Nature (Lond.), 188, 1110.

Sampson, J. J. (1958). Serum transaminase and other enzymes $\overrightarrow{T h}_{\mathrm{T}}$ acute myocardial infarction. Progr. cardiovasc. Dis., 1, 187.

Snyder, D. D., Barnard, C. N., Varco, R. L., and Lillehei, C. 苇 (1958). Serum transaminase patterns following intracardiac surgery. Surgery, 44, 1083.

Sterkel, R. L., Spencer, J. A., Wolfson, S. K. Jr., and Willianse Ashman, H. G. (1958). Serum isocitric dehydrogenase activit with particular reference to liver disease. J. Lab. clin. Međ్ 52, 176.

Strandjord, P. E., Thomas, K. E., and White, L. P. (1959). Studies \& isocitric and lactic dehydrogenase in experimental myocardigl infarction. J. clin. Invest., 38, 2111.

Ticktin, H. E., Ostrow, B. H., and Evans, J. M. (1956). Serof glutamic oxaloacetic transaminase in trauma. Clin. Res. Proç., 4, 102.

Walker, W. F., and Morgan, H. G. (1964). Plasma-transaminase levels in cardiac surgery with extracorporeal circulation. Lancet, 1, 683.

Werle, E., Trautschold, I., Gorriz, A., and Zill, R. (1961). Uber das Verhalten der Aktivität von Serum-Glutamat-Oxalacetâ? Transaminase, Glutamat-Pyruvat-Transaminase und Milchs äuredehydrogenase nach herzchirurgischen Eingriffen. Clin\% chim. Acta, 6, 99.

White, L. P. (1958). Some enigmas in the comparison of multipfe serum enzyme levels. Ann. N. Y. Acad. Sci., 75, 349.

Wieme, R. J. (1962). $\alpha$-Hydroxybutyric dehydrogenase in the diagno of myocardial infarction. Lancet, 2,304 